\title{
The Future International Monetary System: Dominant Currencies or Supranational Money? An Introduction
}

\author{
Michele Fratianni
}

Published online: 31 December 2011

(C) Springer Science+Business Media, LLC 2012

For quite some time the international monetary system has been incapable of delivering external balances or facilitating smooth adjustments of large imbalances. There is a convergence of interests for the status quo: the United States is keen to preserve the benefits it receives as the key-currency country, while creditor countries continue to accumulate dollar-denominated assets and sterilize increases in the foreign component of the monetary base. This special issue of Open Economies Review revisits the mechanism of the existing international monetary system and, in the process, highlights what is not working and what could be done to fix it. The planning of the issue took place in 2010, after the subprime financial crisis but before the onset of the sovereign debt crisis. The severity of the latter and the potential that its resolution may lead to a break-up of the euro area underscores the fragility of the international monetary system and the urgency to reform it. In what follows I concentrate on three main issues: competition among international currencies, the deteriorating dollar standard and Special Drawing Rights, and rules and burden sharing of external adjustment.

\section{International Currencies}

National currencies tend to dominate foreign currencies as means of exchange partly because the bulk of transactions is local and partly because governments discriminate in favor of the currency they issue. Currency substitution - the replacement of domestic money with a (better) foreign money — is a slow process even when it is

Comments and suggestions by Benjamin Cohen, Juan Carlos Martinez Oliva, Andrea Presbitero, and George Tavlas are gratefully acknowledged.

M. Fratianni $(\bowtie)$

Kelley School of Business, Indiana University, Bloomington, IN 47405, USA

e-mail: fratiann@indiana.edu

M. Fratianni

Department of Economics and MoFiR, Università Politecnica delle Marche, Ancona, Italy 
permissible. At the international level, where legal restrictions matter much less, national currencies can compete and seek to reach international status. In the search for the preferred currency, transaction costs are one of the most relevant considerations. These costs decline as the transaction domain of a currency expands; call this the network value of money. Currencies that are not widely used have a low network value and are at a competitive disadvantage against widely-used currencies. Once a currency reaches a dominant network value, it may gain from inertia: upcoming currencies, with similarly low transaction costs, may not be able to upstage the dominant currency quickly (Rey 2001).

There is some historical evidence that, in the competition for international status, very few monies survive both as international media of exchange and stores of value. The Athenian drachma (the "owl") was the first world currency; the Byzantine solidus was the unchallenged coin from the fifth to the seventh century; Roberto Lopez (1951) called it the dollar of the Middle Ages. But the international role of the solidus was eventually challenged by the Islamic dinar, which eventually made the cross over. Both remained international monies until the twelfth century. In the thirteenth century, the Italian coins came to prominence: the Genoese genoino, the Florentine fiorino, and the Venetian ducato. The three coins circulated side by side, in a sort of triumvirate, for quite some time (Cipolla 1956). In the 19th century, the British pound became the leading international currency in sympathy with the economic and political power of Britain. British preeminence came to an end after World War I as the United States emerged as the leading nation.

The emergence of the dollar as an international money dates to the time of World War I. The essay by Barry Eichengreen and Marc Flandreau (2012:57, in this volume) provides detailed evidence that the market for dollar acceptances came alive by 1915 , nudged by the interventions of the Fed. This evidence is consistent with the hypothesis that "lock-in" effects, generated by network externalities, are not sufficiently strong to prevent the emergence of newcomers, although one is not sure whether the dollar and New York would have been effective challengers, as early as in the 1920s, to the pound and London respectively without the Fed's helping hand.

International currency cross-overs do not lead necessarily to the incumbent currency fading away quickly. After World War I, the pound retained its key-currency status for at least four more decades (Eichengreen 2005). As late as 1965, 20 per cent of official reserves were denominated in pound. Thus, in addition to surmountable "lock-in" effects, there is strong inertia in favor of the incumbent international currency. All of this historical evidence suggests that the world of international currencies is closer to an aristocracy than to a monarchy: the position of the leading currency can be contested, but once a successful challenge has been launched the once leading currency does not fall into oblivion.

International-currency status is too broad a generalization. A refinement by functions helps us to understand better differences in contestability and persistence. The now standard taxonomy of the different functions of an international currency, attributable to Cohen (1971), is to invoice internationally traded goods and services, to trade in foreign exchange markets and in its role as the instrument of intervention currency on the part of monetary authorities, to denominate assets held by both monetary authorities and the private sector, and to serve as a reference currency in defining fixed exchange rates. Using this classification system, we can visualize 
international currencies forming a pyramid (Cohen 2012, in this volume and earlier writings). At the peak sits the top currency, the US dollar, which fulfills all of the above roles dominantly and globally; below are the "patrician" currencies- the euro and the yen - that fulfill the same roles but with less intensity and more at a regional than at a global level, and then on a third tier one finds "elite" currencies - the pound and the Swiss franc - that fulfill only some of the roles with even less intensity. Similar currency pyramids can be constructed for earlier periods. Under the pre-WWI international gold standard, for example, the British pound was the top currency and the French franc and German mark the patrician currencies.

What are the benefits of issuing a top international currency? Much of the quantifiable benefit accruing to the United States from the international role of the dollar comes from being the banker of the world (Despres et al. 1966), that is the chief seeker of short-term funds from the rest of the world and the chief source of long-term funds to the rest of the world. In addition to short-term liabilities, the United States can issue fixed-income obligations that are leveraged to effect investments abroad in the form of illiquid foreign direct investments and equities that have great potential for capital gains (Gourinchas and Rey 2005). The sizeable excess rates of return on U.S. assets over U.S. liabilities capture part of the "exorbitant privilege" of having a dominant international currency. But there is more than pecuniary gains. As Benjamin Cohen (2012:13, in this volume) puts it, “...the foundation of monetary power is the capacity to avoid the burden of adjustment required by payments imbalance -an ability to delay adjustment or deflect its costs onto others" (page 18). In other words, the key-currency country is distinct in that it can ignore the external constraint, if not forever for at least a long time.

Yet, despite these benefits it is not obvious that countries of patrician or elite currencies are eager to make the additional investment to move up in the currency pyramid ladder. Two historical episodes, one involving Germany and the other Japan, suggest that currency internationalization may be viewed more as a burden than a privilege. In the nineteen seventies and eighties, the Bundesbank repeatedly opposed internationalization of the German mark reasoning that such a process would make the domestic demand for money unstable and put its objective of achieving low inflation rates at risk. In Japan, opposition to the internationalization of the yen (at approximately the same time of German opposition), instead, came from the export sector that feared a loss of competitiveness resulting from an appreciation of the yen.

The obvious question is: How can one reconcile the assessments of "privilege" and "burden" associated with the status of a top international currency. The answer may come from a sectoral analysis of the distribution of benefits and costs. The essay by Eric Helleiner and Anton Malkin (2012:33, in this volume) start with the premise that policymaking on currency internationalization “.... is influenced not just by calculations of the national (or regional) interest but also by lobbying from specific sectoral groups within issuing jurisdictions who experience these costs and benefits in different ways." Lobbying efforts, as one would expect, rise as net benefits or net costs rise for a given group. Net benefits from currency internationalization accrue to part of the domestic banking sector (money-center banks) and the traded sector, which enjoys a lower cost of hedging exchange rate risk. On the other hand, a discrete step-up in internationalization, followed by an appreciation of the (internationalized) domestic currency, has a negative impact on the competitiveness of the 
export sector, which therefore has an incentive to oppose internationalization. Opposition to internationalization comes also from the non-traded sector if domestic goals are perceived to lose relative to currency stability. For example, currency internationalization implies a liberalization of domestic credit markets and the abandonment of credit allocations. Helleiner and Malkin argue that the internationalization of the Chinese yuan finds a serious obstacle, not only in Chinese manufacturing that fears an appreciation of the yuan, but also in the central government that "maintains a firm grip on credit creation and on the ways in which banks make lending decisions... This organization of credit is a key to China's overall economic growth model..." (page 52). In sum, since there is no assurance that perception of the net benefits of currency internationalization reflect the aggregation of the net benefits of the various sectors of the economy; a "privilege" or a "burden" may be the outcome of different sectoral weights attached to the impact of currency internationalization.

Different assessments of "privilege" and "burdens" may be reconciled by the passage of time. What was once a privilege (for the aggregate) can turn into a burden. The financial crisis of 2007-2009 inspired some American authors to reassess the net benefits the United States receives from a global dollar. These authors, whose works are reviewed by Helleiner and Malkin, believe that the time has come for the dollar to pass the baton of international currency leadership to other national currencies or to the Special Drawing Rights (SDRs). The reasons range from fears that the United States, worried about the deterioration of the international reputation of the dollar, may limit the scope of domestic policy autonomy to an improved quality of fiscal policy achieved by a hardening of the soft external constraint associated with the exorbitant privilege of the dollar. To be sure, there is no indication that such sentiments are shared by US policy makers. But even if they were, there is no national currency ready to replace the US dollar. The euro, the highest ranking patrician currency, has the serious, if not fatal, handicap of not being backed by a political union. Lack of fiscal and political unification in the euro area is exacerbating the current sovereign debt crisis and putting at risk the very existence of the common currency. Japan has neither sufficient economic and political power nor the appetite to see the yen come to the top. The road to complete the yuan internationalization is long and, as we have seen, it is not clear that such a step is in the interest of the Chinese leadership.

Absence of good national alternatives to the dollar may be consistent with a hypothesis that a top international currency is a sort of international public good with large fixed costs that can be borne only by dominant nations, where the qualifier dominant encompasses not only economic muscle but also military power. Cohen (2012) notes that economists have traditionally neglected the connection between international money and geopolitics. Yet, a strong presence in the world enhances the formation of global rules of the game, an environment propitious for a dominant international currency. Adam Posen (2008), cited by Cohen, is a proponent of the currency-geopolitics connection:

The United States' political leadership in security, commercial and even cultural affairs globally has a critical impact on the usage of the dollar in the monetary realm. Other governments' reserve currency holdings and exchange rate management are importantly influenced by security ties, and thus decisions to link 
to the dollar (and to accumulate dollar reserves for intervention) from Taiwan to Saudi Arabia to Panama depend as much on foreign policy as economics. Private decisions to invest in the United States, both at the corporate level and by individuals, are supported by the desire to gain insider access to key decision-making processes and to membership in transnational elites; in fact, it is this desire for membership and access that is a major source of the financially unrewarding investments made by foreigners in the United States - and thus of the United States' exorbitant privilege to pay for its current-account deficits in its own currency. The European Union, let alone the euro zone itself, is unable or unwilling to offer these systemic or security benefits beyond a very limited area, and thus is fundamentally limited in its ability to attract currency adherents, despite the success of the euro on its own terms as a currency and store of value. (page 80).

Giovanni Pittaluga and Elena Seghezza (2012:89, in this volume) formalize this connection with a model of a political hegemon that substitutes for a supranational authority. The mechanics of their search-theoretic construct is relatively straightforward. There are two countries in the world, trading one good with two national monies. One money, issued by the home country, is used only domestically, and the other, issued by the foreign country, has the potential for becoming international because the foreign country invests in institutions that create and maintain trust in its currency. This trust affects the probability of an exchange of goods for foreign money. Both countries tax exchanges by expropriating, with a given probability, a portion of the money (i.e., seigniorage). The home country taxes only domestic residents, whereas the foreign country taxes both domestic and foreign residents. The larger tax base of the foreign country serves to pay for the public good "international monetary order." The welfare of the two countries responds positively to consumption and negatively to the relative gains from foreign country's seigniorage. The authors make the critical assumption that countries care about their relative power position: if the difference in power is small, relative gains from seigniorage matter a lot; conversely, if the difference in power is large, relative gains matter little. Relative power drives the welfare solutions. A foreign hegemon (i.e., a big difference in power) provides large trade opportunities and imposes little disutility on the home country. The foreign country gains as well because its currency is widely used and seigniorage covers the cost of the international public good. As countries become more equal, welfare falls. In an n-country setting, seigniorage would have to be divided among many foreign countries that potentially compete to isssue an international currency, leaving individual amounts that could prove inadequate to pay for the production of trust in international monies. In sum, the benefits of having a dominant currency stem from the ability of the political hegemon to invest in the costly international public good and pay for it by taxing the international community. This is the reason that the euro, according to Pittaluga and Seghezza, is an improbable threat to the dollar.

Under the impetus of the G20, the SDRs have come back to life after years of dormancy. In August of 2009, a new allocation of SDRs, equivalent to \$250 billion, was distributed. For the G20 and the IMF, SDRs are now expected to play a significant role in strengthening the working of the international monetary system. 
It is too early to say whether the time has come for the SDR to contend for a position as a top international currency. Michael Bordo and Harold James (2012, in this volume) review the prospects of basket currencies, including the SDRs, to replace existing reserve currencies and conclude that: "The world looks to the dollar because it is the largest and most liquid market of the world, and because of its political security. Almost everyone, including many Americans, agree that the international role of the dollar is a terrible solution to the world's currency problems. It is just that every alternative is even worse." (page 126)

Yet, the idea of a supranational money, issued and managed by a collection of nations, endures. It is true that the SDRs, in their present form, are neither money nor credit. That form, as Bordo and James remind us, reflects the highly polarized national positions at the time of the creation of that instrument, which was "surrounded by a protective web of regulations" (page 120). The ambiguous nature of the SDRs was facetiously likened to the zebra problem: is the white set on black or the black set on white? It is also true that the reason why SDRs were conceived-a response to the debate on the adequacy of international reserves of the nineteen sixties - is no longer with us. What remains outstanding, however, is the quality of the dollar standard; more on this subject below.

\section{The Deteriorating Dollar Standard and SDRs}

The monetary authorities of a national money that is also used internationally face a conflict between pursuing domestic objectives related to employment and/or inflation and maintaining the international public good of a stable money. There are circumstances in which the two sets of objectives cannot be reconciled and the authorities must choose between them. In the post World War II era-with complete suffrage and a political system more reactive to pressure groups - conflicts between domestic and external objectives have often been resolved in favor of the former. This situation has been particularly true for the United States, which has enjoyed a soft external constraint (Alessandrini and Fratianni 2009). During the heyday of the BrettonWoods era (the nineteen sixties), the United States generated an inflation rate that was consistent neither with the fixed dollar-gold conversion price nor with the preferences of other major players like Germany. The par-value system and dollar convertibility are long gone, but other elements of the Bretton Woods system remain in place, including the IMF. A new periphery of emerging economies, primarily Asian, and oil-producing economies have set undervalued exchange rates with respect to the dollar (Dooley et al. 2003). The central banks of these economies have bought dollar-denominated short-term assets in the foreign exchange markets to prevent or slow an appreciation of their domestic currencies. These interventions have expanded the intervening economies' monetary bases and, with incomplete sterilization, have generated inflationary pressures. In sum, US monetary policy has affected the rest of the world through the workings of the dollar standard; see Ronald McKinnon (2012:109, in this volume). ${ }^{1}$

\footnotetext{
${ }^{1}$ To a similar conclusion arrive Dellas and Tavlas (2011) who argue that the fiat-money-based dollar standard, unlike the old gold-dollar exchange standard, has an inflationary bias.
} 
The deterioration of the dollar standard has its roots in the fact that the US economy has been spending beyond its domestic output for quite some time. Table 1 below presents data on the US current-account balance-which captures the difference between the excess of domestic absorption and domestic output-from 1973 to 2010, in both billions of dollars and percentage of US GDP. To emphasize trends, I consider multi-year periods. From 1973 to 2010, the United States has accumulated deficits of $\$ 8.2$ trillion, at an average yearly rate of $2.2 \%$ of US GDP. More important, external deficits have been rising over time: from virtual balance in the nineteen seventies to yearly deficits averaging $1.8 \%$ of GDP in the nineteen eighties, $1.9 \%$ of GDP in the nineteen nineties, $5.0 \%$ of GDP in the new millennium up until the year before the onset of the financial crisis, and $3.6 \%$ of GDP during the crisis period of 2008-2010.

In theory, as Cohen (this volume) notes, the increase in the supply of reserve assets need not be associated with a current-account deficit. ${ }^{2}$ However, it has happened with the United States since the nineteen eighties. Table 1 shows the cumulative creation of dollar reserve assets by periods. Only in the first subperiod, 1973 through 1980, there has been a negative association between the current-account position of the United States, the supplier of reserve assets, and reserve-asset creation. For the other periods, the association has been positive, often strongly so. In fact, from the end of the Bretton Woods regime to 2010, the United States has supplied \$4.2 trillion of reserve assets to the rest of the world, with an average yearly financing ratio-the fraction of the current-account deficit financed by US short-term liabilities - of 51 per cent. This financing ratio has ranged from a minimum of 7 per cent in the period 1981-1985 to a maximum of 91 per cent in the period 2008-2010. In sum, a large fraction of US current-account deficits has been financed with dollar liquidity creation, thus establishing an empirical association between excessive US spending and world liquidity. Such an observation is consistent with the high growth of international reserves; ${ }^{3}$ with McKinnon's argument that "the Fed [is] an engine of worldwide inflation"; and with the sizeable reduction in the dollar shares of international reserves. ${ }^{4}$ In sum, the dollar standard is weakening.

The paper by Pietro Alessandrini and Andrea Presbitero (2012:129, in this volume) starts with the premise that the international monetary system is sufficiently fragile to warrant a significant modification through the elevation of the role of the SDR, the prospective international "collective" money. To be sure, the choice of targeting the SDR, rather than an alternative imaginary supranational money, has a lot to do with the growing political consensus that is gathering around the SDR. Yet, the basic principles underlying the authors' proposal are those of Keynes' old plan for bancor

\footnotetext{
${ }^{2}$ It is the sum of the current-account balance plus the financial account balance and the net flows of official reserves that must be zero, leaving the possibility of various combinations among these three components of the balance of payments.

${ }^{3}$ International reserves have been growing at an average annual rate of 11 per cent from 1995 to mid 2007, with a sharp acceleration taking place since 2003 when China began increasing sharply its stock of international reserves.

${ }^{4}$ The dollar share in international reserves has fallen from $71.1 \%$ in 2001 to $60.7 \%$ in the first quarter of 2011 (IMF 2011, Figure 1). Considering that the unallocated share in international reserves has more than doubled over the same period, the actual decline of the dollar share is likely to be even larger.
} 
Table 1 US current-account balance and reserve financing, 1973-2010

\begin{tabular}{|c|c|c|c|c|}
\hline \multirow[t]{2}{*}{ Period } & \multicolumn{2}{|c|}{$\begin{array}{l}\text { Cumulative current-account balance, } \\
\text { surplus }(+) \text { or deficit }(-)\end{array}$} & \multirow[t]{2}{*}{$\begin{array}{l}\text { Cumulative changes in } \\
\text { foreign reserves, } \$ \text { billions }\end{array}$} & \multirow[t]{2}{*}{$\begin{array}{l}\text { Reserve financing ratio, } \\
\text { per cent }\end{array}$} \\
\hline & \$ billions & per cent US GDP & & \\
\hline $1973-1980$ & 4 & 0.1 & 116 & \\
\hline 1981-1985 & -252 & -1.3 & 17 & 7 \\
\hline 1986-1990 & -607 & -2.5 & 163 & 27 \\
\hline 1991-1995 & -369 & -1.1 & 279 & 76 \\
\hline 1996-2000 & -1198 & -2.6 & 212 & 18 \\
\hline 2001-2007 & -4258 & -5.0 & 2048 & 48 \\
\hline $2008-2010$ & -1524 & -3.6 & 1385 & 91 \\
\hline
\end{tabular}

Column 2 is the period sum of line 77, "balance on current account" (BEA); column 3 is the ratio of column 2 to US GDP (FRED) multiplied by 100; column 4 is the period sum of line 56, "foreign official assets in the United States" (BEA); column 5 is the ratio of column 4 to column 2 multiplied by 100 . Sources: US Department of Commerce, Bureau of Economic Analysis (BEA), US International Transactions, 1960present and Federal Reserve Bank of St. Louis, FRED database

and an international clearing union, the same plan that Keynes believed was a "thoroughbred animal" that lost to an animal of "mixed origin" (the gold dollar exchange standard) when the Bretton Woods regime was conceived. ${ }^{5}$ These principles tend to resurface in times of stress. ${ }^{6}$ The proposal by Alessandrini and Presbitero goes farther and links the SDRs to development finance, an issue of some importance in the literature of the nineteen seventies.

A few features of this proposal are worth stressing. First, as for the case of national monetary policy, SDR creation has an autonomous, policy driven, supply and an endogenous demand-driven supply. The endogenous component can be constrained by policy through either penalty interest rates or quantitative ceilings. Second, the SDR's reputation stems in part from the reputation of the currencies in the basket. The long-standing concern that there is an inflation bias imbedded in a scheme of this type should be tempered by the fact that SDRdenominated deposits reflect the policy rates set by the high-reputation central banks that manage the national monies included in the basket. Third, SDRs do not replace existing international monies. The extent of the co-existence of SDRs with national currencies would be determined on the demand side of the international-reserve market, where participants can set their preferred portfolios through the mechanism of a substitution account. Adjustments between reserves issued by international agents and reserves issued by other countries would be symmetric. In particular, the United States would no longer benefit from the

\footnotetext{
5 The exact metaphor reads as follows: "The loss of the dog we need not too much regret, though I still think that it was a more thoroughbred animal than what has now come out from a mixed marriage of ideas. Yet, perhaps, as sometimes occurs, this dog of mixed origin is a sturdier and more serviceable animal." (John Maynard Keynes, speech delivered to the House of Lords on May 23, 1944).

${ }^{6}$ With Alessandrini I have applied the same principles for a proposal to create an asset-backed international money (Alessandrini and Fratianni 2009).
} 
automatic stabilizer it has in the dollar standard. The new SDRs would be managed actively by the IMF. Fourth, poor countries would receive a disproportionate share (relative to IMF quotas) of SDRs. While there is an element of equity in these super-allocations, efficiency also plays a role in the sense that unconditional (albeit subject to a ceiling) and predictable injections of international money would tend to overcome some of "the flaws of standard aid assistance, such as donor fragmentation, political influence, and volatility" (page 147).

\section{Rules and Burden Sharing of External Adjustment}

The design and implementation of rules to reduce or eliminate external imbalances are an important aspect of an international monetary system, indeed the most important one according to John Williamson (2012:151, in this volume). Current-account deficits, even under flexible exchange rates, cannot be sustained if they lead to a critical level of foreign debt (40 per cent of GDP) beyond which statistically defaults are more likely to occur. Based on this threshold and current economic growth rates enjoyed by the emerging economies (7.0 per cent), Williamson suggests a prudent objective of keeping current-account deficits within 3.0 per cent of GDP. ${ }^{7}$ As to the way to correct external imbalances, Williamson argues for an application of James Meade's classic prescription of the nineteen fifties by countries adhering to adjustable pegs and of the eighteenth-century analysis of the price-specie flow by David Hume for countries adhering to fixed exchange rates.

An extension of Williamson's analysis on correcting external imbalances is provided by Andrew Hughes-Hallett and Juan Carlos Martinez Oliva (2012:163, in this volume) who consider limits on current-account imbalances and exchange rate movements with a view to achieve a stable steady state equilibrium in the current-account balance, while world portfolio holders willingly hold the home country's stock of foreign debt. The model applies to both reserve currency and non-reserve currency countries and, thus, the implications of an "exorbitant privilege" gained by a reserve-currency country are not analyzed. The model can be represented graphically by two curves relating the domestic real exchange rate to the net debt position of the domestic economy, one determining current-account balance and the other determining portfolio balance. ${ }^{8}$ The steady state can be either stable or unstable depending on the relative slopes of the two curves. Given the presence of multiple equilibria in the model, the authors define a "trade space" area where current-account deficits and net foreign assets or debt are safe to operate. Policy can assist by heading the economy into the stable zone of the

\footnotetext{
${ }^{7}$ Others have suggested different ceilings; for example, US Treasury Secretary Geithner has proposed a ceiling of 4\% (Hughes-Hallett and Martinez Oliva 2012).

${ }^{8}$ The domestic real exchange rate is defined as the ratio of domestic to foreign goods expressed in the same currency. For given values of domestic and foreign prices, real appreciations of the domestic currency translate into nominal appreciations if exchange rates move. In the model, the real exchange rate responds to changes in the net debt position of the economy, which in turn is affected by the current-account balance.
} 
trade space. Barring large negative shocks, a major assumption, the stable zone is characterized by portfolio balances being less elastic than trade balances to changes in the real exchange rate. ${ }^{9}$ Thus, policy should aim at raising the exchange-rate elasticity of the current-account balance and limiting that of the portfolio balance: this objective translates into targeting safe levels of net foreign debt and leaving current-account imbalances to adapt endogenously, a conclusion that runs in the opposite direction of setting current-account limits.

Under fixed exchange rates, the short-run adjusting variable is flows of international reserves. Under flexible exchange rates, the short-run adjusting variable is changes in the exchange rates. Are the latter too volatile relative to underlying fundamentals? The literature answers in the affirmative by looking at evidence in the transition from a fixed rate to a flexible rate regime. This literature concludes that the missing volatility, under fixed rates, is absorbed by international reserves. The paper by Ivo Arnold, Ronald MacDonald and Casper de Vries (2012:193, in this volume) presents empirical evidence showing, instead, that the volatility of IMF support to the central bank has been more important than that of international reserves. The new finding raises two issues. The first is the reason we do not include IMF support as part of international reserves. The second is the extent to which the results are sensitive to the use of the dollar as a numéraire; in fact, Arnold et al. find that IMF support absorbs less excess volatility if the mark replaces the dollar as a numéraire.

The answer to the first point comes from the asymmetric treatment of international reserves in the statistics. As long as a country has not overdrawn its quota, the difference between the quota and use of IMF credit is included in official reserves. If the quota has been exceeded, use of IMF credit above the quota limit is booked as IMF's holdings of that particular currency. On the second point, the authors find no distinct IMF credit effect when they run German mark regressions exclusively for the European Monetary System (EMS) countries on the Bretton Woods period data. A plausible explanation for this result is that it was Germany, rather than other EMS countries, to conduct interventions for the EMS system. ${ }^{10}$

Burden sharing has been a perennial problem for the international community. The well known Keynesian principle of symmetric responsibility implies that surplus and deficit countries ought to share the burden of adjustment. The general rule is if inflation prevails, the burden of adjustment falls primarily on the deficit country. If unemployment prevails, it is up to the surplus country to take an expansionary action. In practice, as Williamson (2012) notes, both surplus countries and deficit reserve-center countries tend to ignore this rule; the former because they give little weight to the effects of reserve accumulation and the latter because they enjoy the privilege of issuing an international currency. Today, the rule is even easier to circumvent by shifting reserve assets from monetary authorities to sovereign wealth funds. On the other hand, should the SDRs become a truly

\footnotetext{
${ }^{9}$ The model is based on an elasticity approach. The authors provide a lengthy explanation of the reason their choice is preferable to the more common approach of dynamic stochastic general equilibrium where stability occurs through the anticipated actions of agents.

${ }^{10}$ These interventions typically preceded a revaluation of the German mark and the Dutch guilder.
} 
Table 2 Cumulative currentaccount balances as a per cent of GDP in selected euro-area countries, 1999-2011

\begin{tabular}{lr}
\hline Netherlands & 71.9 \\
Germany & 47.1 \\
Belgium & 31.6 \\
Austria & 25.4 \\
France & -0.8 \\
Italy & -21.4 \\
Spain & -72.3 \\
Greece & -116.5 \\
Portugal & -125.8 \\
\hline
\end{tabular}

IMF, World Economic Outlook

Database, http://www.imf.org/ external/pubs/ft/weo/2011/02/ weodata/index.aspx

international money, dollar reserve assets could be replaced with SDR deposits and bring about a non-sterilizable monetary correction on the part of the United States (Alessandrini and Fratianni 2009).

How would the symmetric responsibility rule apply to today's euro area? In the last 2 years, public attention has focused more on the banking and sovereign debt crises than on external imbalances within the euro area. This focus has been fostered in part by the neglect of the Eurosystem in analyzing the potential impact of such imbalances on the stability of the euro area. ${ }^{11}$ Table 2 shows that cumulative current-account balances, over the period 1999-2011, range from a surplus of 72 per cent of GDP of the Netherlands to a deficit of 126 per cent of Portugal. Germany, Belgium and Austria have experienced large surpluses; Italy, Spain and Greece large deficits. ${ }^{12}$ Currencies of deficit countries have experienced real-exchange-rate appreciation relative to the mark as a result of positive inflation rate differentials. ${ }^{13}$

As a first approximation, the EMU is divided between a North in surplus and a South in deficit. To eliminate these imbalances, the Humean mechanism would call for a disinflation of prices and wages in the South relative to the North or, equivalently, for an inflation of the North relative to the South. The symmetric responsibility rule points instead to the North as being responsible for a reflation, given that economic conditions in the Southern euro area are depressed. What we are observing is exactly the opposite: the South is undertaking austerity programs under the prodding of the North. This is another example of the fact that surplus countries have the upper hand in the determination of burden sharing. The risk in this case, however, is that the Humean mechanism cannot be applied strongly enough to correct the problem and that some euro area countries may be forced to re-introduce a national currency and effect an exchange-rate change; in other words, a break-up of the euro zone.

\footnotetext{
${ }^{11}$ This neglect is reflected by the lack of adequate data on intra-EMU current-account surpluses and deficits.

${ }^{12}$ Without comparable intra-EMU data, trade balances can be used as rough proxies of the geographic distribution of external imbalances. For example, Germany has accumulated global trade surpluses of $\$ 1,588$ billion in the period $1999-2008$, of which $\$ 700$ billion with respect to the euro area. Italy, on the other hand, has had a much larger cumulative trade deficit with respect to the euro area, $-\$ 89$ billion, than with respect to the rest of the world, $-\$ 32$ billion (Hankel et al. 2010, Tables 7 and 8).

${ }^{13}$ Over the period 1999-2011, Italy has had a cumulative inflation rate (consumer prices) difference relative to Germany of $7.2 \%$, Portugal of 8.6 per cent, Spain of 15.3 per cent, and Greece of 18.5 per cent (IMF, World Economic Outlook database).
} 


\section{References}

Alessandrini P, Fratianni M (2009) Resurrecting Keynes to stabilize the international monetary system. Open Econ Rev 20(3):339-358

Alessandrini P, Presbitero A (2012) Low-income countries and an SDR-based international monetary system, in this volume

Arnold IJM, MacDonald R, de Vries C (2012) IMF Support and inter-regime exchange rate volatility, in this volume

Bordo MD, James H (2012) Reserves and baskets, in this volume

Cipolla CM (1956) Money, prices, and civilization in the mediterranean world. Princeton University Press, Princeton

Cohen BJ (1971) The future of sterling as an international currency. Macmillan, London

Cohen BJ (2012) The benefits and costs of an international currency: getting the calculus right, in this volume

Dellas H, Tavlas GS (2011) The fatal flaw: the revived bretton woods system, liquidity creation, and asset price bubbles. Cato J 31(3):485-495

Despres E, Kindleberger C, Salant W (1966) The dollar and world liquidity: a minority view. The Economist, February 5

Dooley MP, Folkerts-Landau D, Garber P (2003) An essay on the revived Bretton Woods System, NBER Working Paper N. 9971

Eichengreen B (2005) Sterling's past, dollar's future: historical perspectives on reserve currency competition. NBER Working Paper 11336

Eichengreen B, Flandreau M (2012) The Federal Reserve, the Bank of England, and the rise of the dollar as an international currency, 1814-1939, in this volume

Gourinchas P-O, Rey H (2005) From world banker to world venture capitalist: US External Adjustment and the Exorbitant Privilege, National Bureau of Economic Research Working paper no. 11563

Hankel W, Hauskrecht A, Stuart B (2010) The Euro-Project at Risk, Working Paper, University Bonn, Institute for International Economic Policy

Helleiner E, Malkin A (2012) Sectoral interests and global money: Renminbi, dollars and the domestic foundations of international currency policy, in this volume

Hughes-Hallett A, Martinez Oliva JC (2012) Reducing global imbalances: can fixed exchange rates and current-account limits help?, in this volume

International Monetary Fund (IMF) (2011) Criteria for broadening the SDR Currency Basket, September, available at http://www.imf.org/external/np/pp/eng/2011/092311.pdf

Lopez RS (1951) The dollar of the middle ages. J Econ Hist 11:209-234

McKinnon R (2012) The fed as the engine of worldwide inflation, in this volume

Pittaluga G, Seghezza E (2012) Euro vs. Dollar: an improbable threat, in this volume

Posen AS (2008) Why the Euro will not rival the dollar. Int Finance 11(1):75-100

Rey H (2001) International trade and currency exchange. Rev Econ Stud 68(2):443-464

Williamson J (2012) Rules for correcting external imbalances, in this volume 